\title{
The Model Ekphraseis of Nikolaos the Sophist as Memory Images
}

\author{
RUTH WEBB
}

Hidden away in the pages of Libanios' voluminous œuvre is a collection of Late Antique ekphraseis of sculptures which, in contrast to other similar collections, has been largely ignored. These pieces were included by Foerster in his edition of Libanios' model Progymnasmata, despite his doubts about their attribution to this author. ${ }^{1}$ Some of the same works appear under Nikolaos' name in the first volume of Walz's Rhetores graeci, still a treasure trove for anyone interested in Late Antique and Byzantine rhetoric. ${ }^{2}$ This 'Nikolaos' may be the same Nikolaos whose treatise on the writing of the Progymnasmata is one of the four such handbooks to have survived, along with those of Aphthonios, Ps.-Hermogenes and Theon. ${ }^{3}$

These descriptions lie at the intersection of the modern definition of ekphrasis as a 'description of a work of art' and the ancient practice of ekphrasis as a type of vivid speech 'bringing the thing shown before the eyes' taught in rhetorical schools throughout the Roman and Byzantine periods. ${ }^{4}$ In some ways they are comparable to the free-standing rhetorical descriptions of paintings and statues by the Philostrati and Kallistratos, or to the passages within late antique epideictic speeches and poems that celebrate works of visual art. But they are also distinct in that they appear to belong within a scholastic context and also in that they signally fail (in this reader's opinion) to achieve the defining effect of ekphrasis, to

1 Libanios, Progymnasmata, in: Opera VIII, ed. R. Foerster, Leipzig 1915, 491-538. Foerster edited these texts from several manuscripts of the 13th-15th centuries: Paris. Gr. 3016; Vat. Barb. gr. 240; Leiden Vossianus gr. qu. 18. The text is reproduced with a German translation and archaeological commentary in B. D. Hebert, Spätantike Beschreibung von Kunstwerken: Archäologischer Kommentar zu den Ekphraseis des Libanios und Nikolaos (Dissertationen der Karl-Franzens-Universität Graz 60), Graz 1983. An English translation of all of Libanios' Progymnasmata by Craig Gibson is forthcoming from Brill.

2 Rhetores Graeci ed. C. Walz, Stuttgart 1832, 394-414 gives the text of some of these ekphraseis from MS Paris. gr. 2918 which attributes the works to Nikolaos.

3 Nikolaos, Progymnasmata, ed. J. Felten, Leipzig 1913; Aphthonios, Progymnasmata, ed. H. Rabe, Leipzig, 1926; Ps.-Hermogenes, Progymnasmata, in: Hermogenes, Opera, ed. H. Rabe, Leipzig 1913; Theon, Progymnasmata, ed. M. Patillon/G. Bolognesi, Paris 1997.

4 On the question of definition see R. Webb, Ekphrasis ancient and modern: the invention of a genre, in: Word and Image 15 (1999) 7-18. 
appeal to the visual imagination. The interest of these ekphraseis lies precisely in this failure, revealing as they do the tension between the stated aim of ekphrasis to 'place before the eyes' and the practical demands of teaching in the rhetorical schools. They also lay bare, I suggest, one particular function of ekphrasis within the larger rhetorical system, the evocation of a larger narrative context from the inclusion of few telling details. Finally, I suggest an interpretation of these ekphraseis as an attempt to create memory images with a specific cultural agenda to preserve knowledge of the traditional narratives of classical literature.

This group of ekphraseis of sculptures includes representations of an unnamed Trojan woman after the sack of Troy, the sacrifice of Polyxena by Neoptolemos, Prometheus in agony, figures of Hera, Medea, Athena, Ajax and the two Theban brothers, Eteokles and Polyneikes. ${ }^{5}$ All are presented as descriptions of statues that the author claims are visible 'in the city'. But, instead of the eloquent and energetic evocation of scenes and figures that we find in the work of the Elder Philostratos, for example, the reader encounters a lengthy enumeration of the details of gesture, posture, clothing and facial expression. Instead of an impression of the whole, we are presented with a figure broken down into its constituent parts and subjected to a reading in which each detail is accompanied by an explanation of its meaning.

These pieces tend to follow a standard pattern, starting with the geographical location of the events depicted, described as a spectacle in themselves: 'Corinth in Greece witnessed (tetheatai) the terrible deeds of Medeia ...'; 'First of all, Troy saw (eide) Ajax out of his mind ...? 6 The literary and artistic representations of the subjects are then said to have made the story familiar throughout Greece: 'Time saw the sufferings of Troy on the opposite shore perpetrated during the war, after this the stage represented (emimessato) them, and thirdly bronze fashioned itself in the image (apeikazei) of fate. ${ }^{7}$ Drama and sculpture are presented as the means by which knowledge of the historical event was disseminated, with the implication that the sculpture, coming usually in third place as here, depends upon the textual source. They then proceed to describe the statue from head to toe, treating each detail of clothing and gesture as a sign of etthos or pathos. Hera's modest clothing and posture are described in minute detail as indications

5 Libanios, Opera VIII 502-4 (Hera); 504-7 (Trojan woman); 508-511 (Polyxena); 511-516 (Prometheus); 516-518 (Medea); 520-523 (Athena); 524-527 (Ajax); 537-8 (Eteokles and Polyneikes). Other subjects include several depictions of Herakles, a Chimaira and a Peacock and Alexander.

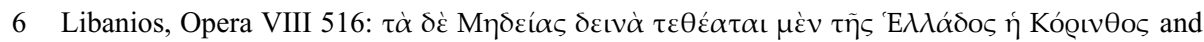

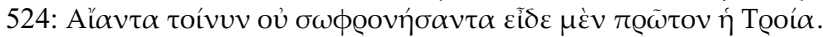

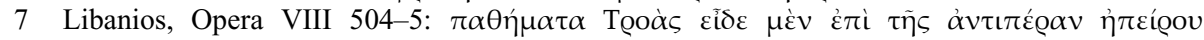

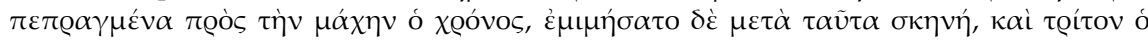

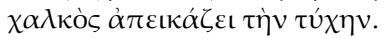


of her function as goddess of matrimony, the lack of a helmet on Ajax's head is said to show his deranged mental state just as the expressions of agony on Prometheus' face and the tension in his body are described as signs of the torture to which he is being subjected. ${ }^{8}$

The ekphrasis of the Trojan woman is a good example of how these descriptions proceed, enumerating details and offering interpretations. The author claims that the figure indicates (semainousa) the fate of her city: she sits on a chair, showing (sèmainousa) that it was not possible for her to stand when her city had fallen, her head was bare, since the fall of her fatherland had taken away shame, yet her headband held back her hair, showing that she retained some sense of shame. ${ }^{9}$ The ekphrasis continues in this vein, detailing and reading the rest of the figure as a sign of the woman's plight, behind which lies the narrative cause, the sack of Troy. The result is that instead of the subtle interweaving of perceptual detail and narrative background that we see in an author like Philostratos the figures are fragmented, broken down into their constituent parts. Instead of the breathless involvement in the scenes depicted that characterises the Philostratean ekphraseis, our anonymous author maintains the distanced stance of an analytical interpreter. ${ }^{10}$ These descriptions are far from vivid, but they may shed light on the techniques, and above all the purposes, of ekphrasis of all kinds in the late antique system of rhetoric.

\section{Rhetorical ekphrasis}

Ekphrasis is defined in the rhetorical handbooks in use in Late Antiquity as an account of anything which was detailed enough to appeal to the audience's imagination, and make them feel they could see it. (In purely technical terms the degree of detail was what distinguished an ekphrasis of a battle, for example, from a diegesis, a narration, or statement of facts, relating the same subject.) To $e k$-phrazein was therefore to tell in full $(e k)$. In his theoretical treatment of ek-

8 On Prometheus in art and the philosophical problems posed by depictions of torture see H. Morales, The Torturer's Apprentice: Parrhasius and the limits of art, in: J. Elsner (ed.), Art and Text in Roman Culture, Cambridge 1996.

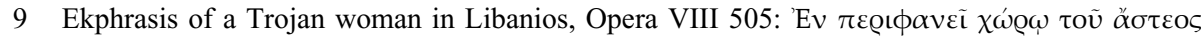

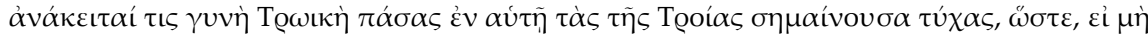

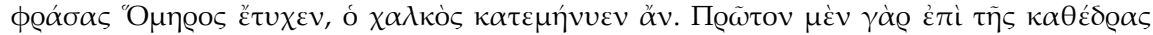

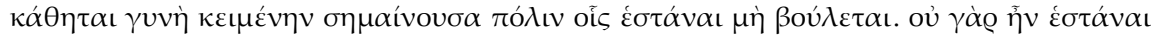

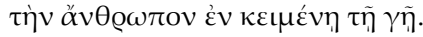

10 On these different stances see Z. Newby, Absorption and erudition in Philostratus' Imagines, in: E. Bowie/J. Elsner (eds.), Philostratus, Cambridge (forthcoming) and R. Webb, Accomplishing the Picture: Ekphrasis, Mimesis and Martyrdom in Asterios of Amaseia, in: L. James (ed.), Art and Text in Byzantium, Cambridge (forthcoming). 
phrasis, Nikolaos (perhaps the author of our pieces, perhaps not) draws a clear distinction between a plain statement of events (psile ekthesis) and an ekphrasis of the same subject which is vivid and 'tries to make listeners into spectators'. ${ }^{11}$ The Roman rhetorician, Quintilian, makes a parallel distinction, without using the Greek term ekphrasis, when he contrasts a plain statement of facts, brevis nuntius, with a developed, circumstantial account of the same subject which makes the audience 'see' it through the quality of enargeia. The example he uses to illustrate this contrast is the sack of a city, a well-worn theme in poetry, rhetoric and historiography, and a favourite in the rhetorical schools often mentioned as a subject of ekphrasis in the Greek manuals. ${ }^{12}$ To say that the city has fallen, he says, conveys the basic information, but the speaker who wishes to move the audience needs to give a developed account, which displays the details to the audience. ${ }^{13}$ The value of Quintilian's analysis is that it explains the function of such passages in a piece of oratory: they serve to move the audience and to make them feel, rather than simply know, by creating an illusion of presence and involvement which is an essential part of persuasion. ${ }^{14}$

Such uses of language to 'place the subject before the eyes of the audience' inevitably suggest a comparison between the orator and the painter. ${ }^{15}$ In his commentary on Aphthonios (a commentary which fills many gaps between the Greek Progymnasmata manuals and the more sophisticated discussion in Quintilian's Institutio oratoria) Johannes Sardianos claims in his discussion of ekphrasis that enargeia 'imitates the art of the painter'. ${ }^{16}$ Given the centrality of the visual within the general definition of ekphrasis, it is not surprising that many of the surviving 'fair-copies' of ekphraseis produced in the ambit of the rhetors' schools are descriptions of statues and paintings of mythological and other subjects, even though works of art barely figure in the surviving discussions of ekphrasis as a rhetorical technique. ${ }^{17}$ In the mannered declamations of the fourth-century rhetor,

11 Nikolaos, Progymnasmata, 68-9.

12 See, for example, Sopatros, On the Division of Questions, in: Rhetores Graeci ed. C. Walz, Stuttgart 1835, VIII 210.

13 Quintilian, Institutio oratoria, 8.3.67-68: Sine dubio enim qui dicit expugnatam esse civitatem complectitur omnia quaecumque talis fortuna recepit, sed in adfectus minus penetrat brevis hic velut nuntius. At si aperias haec, quae verbo uno inclusa erant, apparebunt effusae per domus ac templa flammae ...

14 Quintilian, Institutio oratoria, 8.3.62.

15 See R. Meijering, Literary and Rhetorical Theories in Greek Scholia, Groningen 1987, 37-9.

16 Sardianos, Commentarium in Aphthonii Progymnasmata, ed. H. Rabe, Leipzig 1928, 217 :

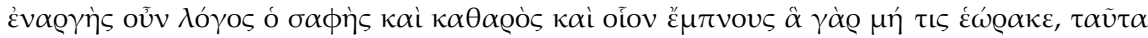

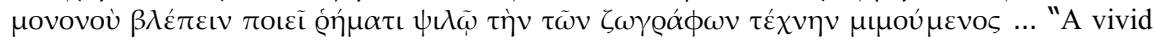
speech is one which is clear and pure and as if alive; by the word alone it makes one all but see what one has not perceived, in imitation of the art of painting".

17 The only version of the progymnasmata to mention paintings and sculptures as subjects is the one attributed to Nikolaos, which probably dates to the fifth century. 
Himerios, an emotive appeal to the audience to 'picture the scene' is presented as a description of a painting in which the orator, tellingly, summons up the artist and his materials as well as the details to be depicted. ${ }^{18}$ But the comparison with the visual arts was not the only, or even the principal, one to which teachers of rhetoric appealed when they wished to express the effect of ekphrasis. Himerios' ekphrasis contains several allusions to the art of tragedy, and theatrical representation was another form of 'placing before the eyes' which was just as potent for ancient writers on ekphrasis (though easy for us to forget because of the evanescence of the theatrical experience). When the authors of the Progymnasmata speak of the way that ekphrasis 'tries to make listeners into spectators', ${ }^{19}$ the term used for the latter is theatai, which suggests first and foremost the model of the theatre ${ }^{20}$ or the presentation of the image as a theatrical event. ${ }^{21}$

It is hard to evaluate the imaginative impact of any text on readers or listeners of another period. But the statue ekphraseis attributed to Nikolaos do seem to depart significantly from the ideal of ekphrasis declared in the ancient handbooks with their references to enargeia. It is noticeable, however, that rhetorical writers have very little in the way of practical advice to give to authors wishing to achieve this quality, beyond the general advice to include details. The Progymnasmata themselves are not particularly helpful in this respect either, rarely venturing beyond general precepts about the organisation of particular ekphraseis: when describing figures start from the head and work down, when describing events start from the first thing to happen and follow a chronological order. ${ }^{22}$

There is therefore some tension between the ideal of ekphrasis - a speech so vivid that it appeals to the imagination, transporting the listeners, making them feel as if they were present - and the practical reality of the rhetorical schools. Teachers needed clear rules and memorable definitions and, in this sense, ekphrasis was always something of an anomaly among the Progymnasmata. It is the only exercise to be defined by its impact on the audience rather than by some easily recognisable formal characteristic and, as Ps.-Hermogenes notes, not all

18 Himerios Or. 4. The passage is translated in D. A. Russell, Greek Declamation, Cambridge 1983, 29-30.

19 Nikolaos, Progymnasmata, 68 and 70.

20 The formula seems to derive from Isocrates, who claims at Nikokles II 49 that drama, in contrast to Homeric epic, makes the audience not only listeners but spectators (theatai).

21 Quintilian, Institutio oratoria, 6.1.32 refers to the practice of displaying paintings of a crime in court (a practice he disapproves of). See Aelianus, Historical Miscellany, ed. and transl. by N. G. Wilson (The Loeb classical library 486), Cambridge 1997, II.44 on the spectacular unveiling of a painting of a hoplite by Theon of Samos to the sound of a trumpet.

22 See Aphthonios, Progymnasmata, 37; Nikolaos, Progymnasmata, 69 (on descriptions of painted and sculpted figures). 
authorities treated it as an independent exercise. ${ }^{23}$ In the school context it is perhaps not surprising that such formal, practical recommendations as there were (such as starting from the head of a figure and working down) were emphasised even if these do not necessarily make a passage appeal to the reader or listener's imagination. The ekphraseis of statues attributed to Nikolaos may well be an example of this tension between theory and practice since they appear to follow the rules for ekphrasis to the letter, privileging the means over the end. If so, this development is an important one as it reveals a change in the way in which ekphrasis in general was perceived and understood. Rather than being solely defined by its impact on the audience, it seems that ekphrasis came to be defined also by more objective characteristics, like profusion of detail. The habit of breaking down an event or object into its constituent parts, articulated by men and de, is a noticeable feature of many Late Antique and Byzantine ekphraseis. ${ }^{24}$ And a further sign of this process can be seen in a Byzantine rhetorical manual in which ekphrasis is characterised first and foremost as a speech that sets out its subject matter in detail (kata lepton). Most strikingly, the reference to detail takes the place of the adverb 'vividly' (enargōs) in the older versions of the Progymnasmata. ${ }^{25}$

The preference for a profusion of detail in place of one or two telling points that could spark an effective mental image may well have been a characteristic of school ekphraseis at all periods. Quintilian (Institutio oratoria 2.4.3) complains about schoolboy excesses in description that need to be reined in, and we can speculate that the isolation of ekphrasis as an independent exercise may well have encouraged this tendency. One example from Nikolaos' treatise on the Progymnasmata shows how concise rhetorical ekphrasis could be in practice. This is Demosthenes' account of the destruction of Phokis (On the False Embassy, 65) which portrays the scene of devastation left by Philip of Macedon in eighteen words: 'houses destroyed, walls razed to the ground, the countryside emptied of its young men, just women and a few small children and old men in a pitiful state

23 Ps.-Hermogenes, Progymnasmata in: Hermogenes, Opera, Leipzig 1913, 23. These authorities argued that ekphrasis was included within other exercises, like narration. The fact that all the extant versions of the Progymnasmata include ekphrasis as an exercise probably reflects the interests of the Late Antique and Byzantine schools and their role in the selection of canonical rhetorical handbooks.

24 See, for example, Libanios' model ekphrasis of a battle in: Opera VIII 460-464.

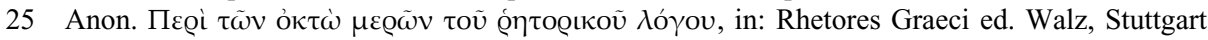

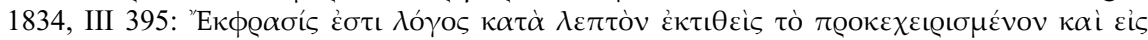

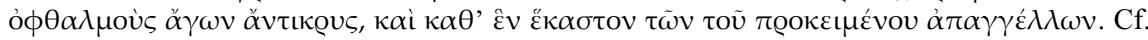
T. M. Conley, Rummaging in Walz's Attic: Two Anonymous Opuscula in Rhetores Graeci, in: GRBS 46 (2006) 101-122 suggests a date between 1261 and 1320. 
$\ldots{ }^{26}$ However, a pupil in the schools of rhetoric would probably not have been able to get away with two lines, however vivid, when asked to compose an example of ekphrasis, however effective his two lines may have been!

\section{Ekphrasis and inference}

Nikolaos' quotation of this passage is of particular interest as he uses it to illustrate one of the possible functions of ekphrasis in a larger speech: to contribute to auxēsis (the verbal underlining of some fact taken as established) and deinōsis (the arousal of indignation). The purpose of this passage within the oration is to make the audience understand the feelings and motivations of those who saw the scene for themselves, specifically to arouse indignation against Philip and his allies. What is noticeable about this passage, and of great importance to the workings of ekphrasis in general, is that the action at which we are supposed to feel outrage (Philip's violence) is not described directly but through the visible traces it left. Yet in order for it to be effective, the audience must supply that information for themselves. The details described are therefore important above all as a sign of something else and we are left to infer the actions which preceded from the sketch of the aftermath alone. ${ }^{27}$

Quintilian cites two parallel passages from Rome's answer to Demosthenes, Cicero. One is a brief sketch of the villainous Verres (Cicero, Verrines, 5.33.86) Another, from a lost speech, evokes a drunken party through a description of its aftermath: the filfthy, winestained floor, covered with wilted wreaths and fish bones. ${ }^{28}$ In all these passages the audience participated actively, inferring further details and associations which took their starting point from the words and their connotations, but went far beyond what is explicitly described. To achieve their effect, Demosthenes' scene of destruction or Cicero's sketch of the chaotic dining room demand that the audience supply further information for themselves. In both these cases the link between the scene described and the further actions which are left implicit is a temporal, narrative one, of effect to cause. Technically, the destruction is a necessary sign (tekmêrion, signum necessarium) of the actions that

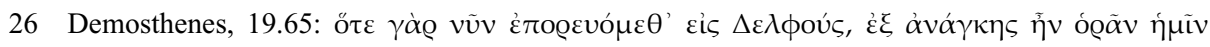

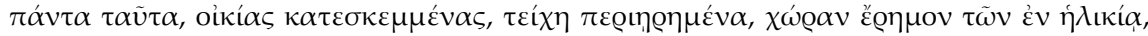

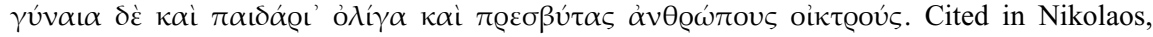
Progymnasmata, 71.

27 Compare Rhetorica ad Herennium IV.39.51 on descriptio.

28 Quintilian, Institutio oratoria, 8.3.66 quoting from Cicero's lost speech Pro Gallio. The description, of course, brings to mind the Roman floor mosaics representing such details. 
caused it while the dress and pose of Verres are probable indications of his character (sēmeia, signa non necessaria). ${ }^{29}$

\section{Ekphrasis, art and signs}

We have strayed a long way from the group of Late Antique ekphraseis of statues that are the subject of this paper. But this detour via Quintilian and the theoretical treatise of Nikolaos was necessary to illustrate an important aspect of rhetorical ekphrasis; that it could demand an active imaginative, emotional, and intellectual response from an audience, rather than simply telling them about the appearance of something. The demand that the audience of the ekphrasis of sacked city supply for themselves the events which led up to this scene of devastation, and of which the devastation is an unmistakable sign, or that they flesh out the sketch of a person with further, emotionally charged, details, again leads us to the analogy with the work of art. The frozen moment or moments depicted in a statue or painting often signify a larger narrative continuum which the viewer has to supply (cf. Latin signum). This is the type of reading of images dramatised by Philostratos in the Eikones where the very first description shows the narrator demonstrating to the boy how the scene before him refers to the Iliad and tells him to turn his eyes away momentarily from the visual spectacle of the painting to consider the narrative background as part of the process of understanding the painting. ${ }^{30}$

This synecdochic relationship between an image and its narrative context was particularly important within an artistic tradition which, as in antiquity and Byzantium, dealt with a range of familiar narratives shared with, or drawn directly from, a body of canonical literature. In his treatise on the Progymnasmata, Nikolaos underlines the importance of the narrative background of statues and paintings when these are used as the subjects of ekphrasis. The author should refer to the emotions and the causes of those emotions in the character's story: 'We must, particularly when we describe statues for example or paintings or things of this sort, try to add reasons (logismoi) why the painter or sculptor depicted things in certain ways, like, for example, that he depicted the character as angry for such and such a cause (aitia) or happy, or we will mention some other

29 See C. Moussy, Signum et les noms latins de la preuve: l'héritage de divers termes grecs, in: J. Dangel (ed.), Grammaire et rhétorique: notion de romanité, Strasbourg 1994, 31-41.

30 The Elder Philostratos, Eikones I.1. See J. Elsner, Art and the Roman Viewer: the Transformation of Art from the Pagan World to Christianity, Cambridge 1995, Chapter 1 on this type of viewing. Aelian praises the painting of a hoplite by Theon of Samos precisely for its capacity to suggest an entire military action through one single figure. 
emotion resulting from the story about the person being described.' Such reasons, he claims, 'contribute greatly to enargeia' in all types of ekphrasis. ${ }^{31}$

The model ekphraseis we are interested in here follow these precepts closely (which may, perhaps, explain why they came to be attributed to Nikolaos). Each detail is no sooner mentioned than it is interpreted in terms of the narrative background and the related thoughts and emotions of the character. Thus Prometheus' dishevelled hair shows his physical torment, Medea bows her head as if unable to bear the sight of the children she has just killed and Ajax's asymmetrical stance is seen as a sign of his mental instability. ${ }^{32}$ This may well reflect the way in which viewers responded to actual works of art, reading the narrative background, with its concomitant associations and emotions, into a frozen moment, and suits a figural tradition which appeals to a set of familiar narratives. An example of precisely this type of reading of a statue that indisputably existed is Prokopios of Caesarea's description of the equestrian statue in front of Hagia Sophia. Prokopios spells out the horse's exact posture, describing it as being as if it were ready to move eastwards, the seated Emperor also looks in the same direction, towards Persia, Prokopios surmises, adding that the sculptor has given him a globe to carry, showing that he rules the whole earth and sea. ${ }^{33}$

But there is also an interesting parallel between the type of reading of visual detail that we see enacted in the model ekphraseis of statues and the response to rhetorical ekphrasis described above. In both, the details supplied by the speaker prompt the listener to supply further information. The difference - and it is an important one - is that these statue ekphraseis verbalise both the detail and the further information that the detail is supposed to evoke, making everything explicit and leaving nothing for the reader or listener to supply. Whereas Demosthenes' audience had to supply for themselves the details of the attack that had caused the scene of devastation he describes, Nikolaos' models carefully supply the reading for each perceptible detail. In this sense, these ekphraseis provide not so much a model of ekphrasis itself as an example of an ekphrasis together with the type of interpretative response that it might be expected to evoke from an

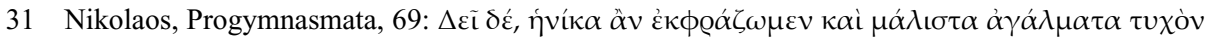

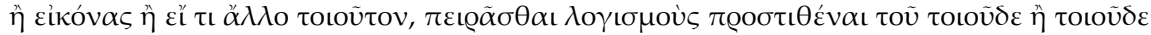

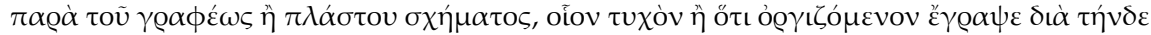

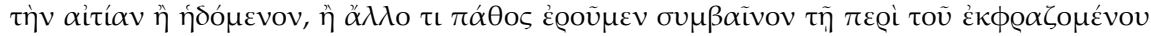

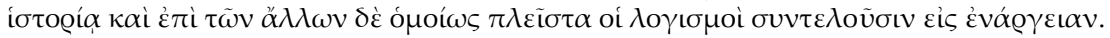

32 Libanios, Opera VIII 512 (Prometheus); 516-517 (Medea); 526-527 (Ajax).

33 Prokopios of Caesarea, Buildings, 1.2.5-12. On this ekphrasis and Prokopios' rhetorical strategies to impose a new meaning on a statue that had been reused see M. Whitby, Pride and Prejudice in Procopius' Buildings: Imperial Images in Constantinople, in: AnTard 8 (2000) 59-66 and R. Webb, Ekphrasis, Amplification and Persuasion in Procopius' Buildings, ibid., 67-71. As Whitby, ibidem 65 points out 'Procopius has maximised the panegyrical impact of his account by ensuring that his audience would infer that the statue depicted Justinian.' 
audience. Nikolaos' models could therefore be described as a kind of metaekphrasis, putting into words both the scene (the figure) and what is to be understood from it (the narrative background and the character and emotions associated with the figure).

\section{The function of Nikolaos' ekphraseis}

We could therefore argue that Nikolaos' model ekphraseis use the idea of the statue to illustrate not just the composition of an ekphrasis but also the type of interpretative response that an ekphrasis could elicit from its audience. The comparison with Prokopios is interesting too in that it underlines what is different about Nikolaos' statue ekphraseis: their mythological content and the lack of specific geographical context. To start with the latter, the introductory formula that recurs in several examples: 'in a prominent place in the city I saw/there lies' gives no clue as to the precise location, meaning that these pieces are tied to no particular place and time and are infinitely reusable, as would fit a schoolroom model. ${ }^{34}$

Secondly, it is noticeable that most of the figures depicted in these statues correspond to precise tragedies that were studied in late antique schools: Euripides' Medea, Hecuba, Trojan Women and Phoinissai (for Eteokles and Polyneikes); Sophocles' Ajax and Antigone (again for Eteokles and Polyneikes) and Aeschylus' Prometheus. The connection is underlined several times by the author of the ekphraseis who makes reference to the representation of the figure in question on the tragic stage. Thus the sufferings of the Trojans, the sacrifice of Polyxena, the madness of Ajax and the misfortunes of Thebes are said to have been depicted first on stage, and then in sculpture. ${ }^{35}$ The ekphraseis are thus placed in a direct chain of transmission since it is implied that the sculpted representations they describe depend upon the tragic versions. What is more, the introductions to the ekphraseis refer again and again to the mythological narratives as actual events that took place or 'were seen' in a specific place, as in the introduction to the ekphrasis of the Trojan Woman quoted above. There, the sufferings of the Trojans are said to have been seen by 'time' (chronos), then represented on stage

34 Only the ekphrasis of the Trojan woman gives a clue to the location of "the city" with its reference to Troy being on the opposite shore, suggesting a Constantinopolitan origin. Libanios,

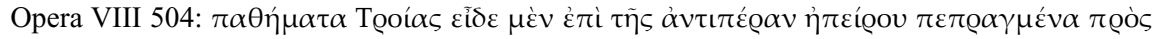

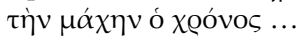

35 Libanios, Opera VIII 504-505 (Ekphrasis of a Trojan woman); 508 (Polyxena) 524 (Ajax); 537 (Eteokles and Polyneikes). 
before their likeness was made in bronze. Only then comes speech $(\log o s)$ - i.e. the ekphrasis - indicating (sēmainōn) what happened in Troy.

The reader of these ekphraseis is therefore placed in a context where the events of the heroic age are the common cultural reference point. The knowledge appealed to corresponds to the knowledge of the educated elite of the Eastern Empire at any time and place. What is striking, however, is the relation that is assumed between the reader and this culture. Whereas Demosthenes' ekphrasis of the misfortunes of the Phokians was composed for an audience who would read it instantaneously as a sign of Philip's treachery and violence, these ekphraseis imply an audience who need to have the link between the figure and the background story laboriously spelled out for them. Again, this appears to confirm the school origin of these pieces. They are not written as puzzles for an erudite audience but for readers who needed to be reminded of the literary and mythological background to the figures. ${ }^{36}$

\section{Ekphrasis and the creation of knowledge}

Given this, I would suggest that these ekphraseis are not, first and foremost, guides to the viewing of statues. Instead, they take the idea of the statue and its ability to represent a pregnant moment to represent in a nutshell some of the key narratives of the school curriculum. Nor do they necessarily represent the shared cultural knowledge of their audience. They appear rather to attempt to create such knowledge in their readers, spelling out the background stories that were attached to an emblematic figure. In describing the signifying body of the Trojan Woman, for example, the author of the ekphrasis creates in his audience's mind the memorable image of a figure that bears the signs of her story and can therefore serve as a permanent reminder of that story in all its details. Although not directly attested in the surviving Greek rhetorical sources, the creation of memory images was recommended by Roman rhetoricians who add that the figures should be striking in order to be memorable. ${ }^{37}$ These statue images are not as bizarre as some of the examples cited in the textbooks but their appeal to common iconographical types makes them easily memorable as does the precision with which each pose is described. The static nature of the figures, which distinguishes these ekphraseis from the living, moving and feeling figures we find in Philostratos and, more to the point, in Kallistratos' ekphraseis of statues, further helps to fix them in the

36 These ekphraseis also differ from Procopius' equestrian statue in this respect: Procopius spells out a meaning for his statue but leaves his audience to make the further inference that the statue represents Justinian, as Whitby points out (see n. 33).

37 Rhetorica ad Herennium, III 20.33. 
mind. ${ }^{38}$ In addition, we may speculate that the prominence of themes of sex and violence made these figures memorable for a young, male audience. The bodies of the female figures in particular are described in great detail, thus, in a detail inspired by Euripides, both the Trojan Woman and Polyxena are said to have torn robes, both have one breast uncovered. In the case of the Trojan woman, the uncovered breast is said to show that her misfortunes have partially taken away her sense of shame (aidoss) and the narrator speculates that she is unaware of her partial nakedness a remark that portrays her as the unwitting object of the male gaze. ${ }^{39}$ References to the characters' modesty that only serve to underline the slightly risque nature of the descriptions. Polyxena, in a direct allusion to the Hecuba is said to have her torn dress kept in place by a belt that keeps covered 'what should not be seen by the eyes of men' and to keep her thighs close together, while in the description of the statue of Hera the narrator, with a great show of modesty, declines to describe what is below the figure's waist. ${ }^{40}$

These particular ekphraseis seem, therefore, to create memory, rather than to appeal to prior knowledge, and seek by so doing to preserve that knowledge. They summon up, painstakingly, an image that can be fixed in the mind and seek to attach narratives and cultural values to each part of that image. The opening formula of the descriptions with its emphasis on the direct transmission of this knowledge - from the heroic age to classical literature to sculpture and then to the author of the ekphrasis - also places emphasis on the survival of tradition and on the role of these ekphraseis themselves in retelling the events of the past. The content of these ekphraseis is so generic that it is difficult to locate them, Nikolaos is located in the second half of the fifth century by the Suda, but the attribution is debatable. However, if these ekphraseis are indeed intended at least partly

38 On Kallistratos see now F. Graziani, "La verité en image”: La méthode sophistique, in: M. Constantini/et al. (eds.), Le défi de l'art: Philostrate, Callistrate et l'image sophistique, Rennes 2006, 137-151.

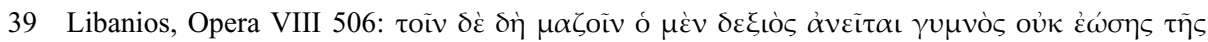

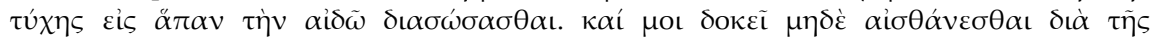

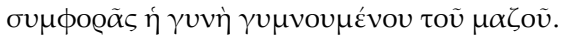

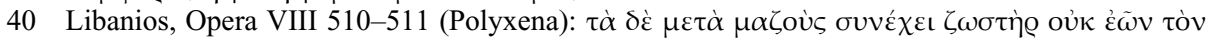

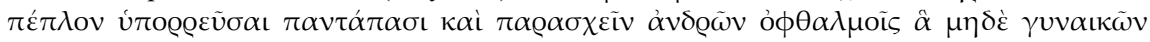

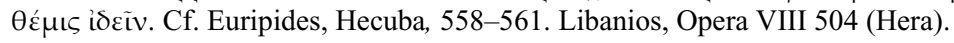


to preserve knowledge of classical literature, they can be compared with the anthologising habits of Late Antiquity and with projects like that of John Stobaeus at the beginning of the fifth century. They also reveal the flexibility of the practice of ekphrasis within the Late Antique rhetorical tradition and the sheer variety of configurations of word, knowledge, imagination and memory that ekphrasis can involve. 
